Conservation Biology of Freshwater Turtles and Tortoises:

A Compilation Project of the IUCN/SSC Tortoise and Freshwater Turtle Specialist Group

A.G.J. Rhodin, P.C.H. Pritchard, P.P. van Dijk, R.A. Saumure, K.A. Buhlmann, and J.B. Iverson, Eds.

Chelonian Research Monographs (ISSN 1088-7105) No. 5, doi:10.3854/crm.5.004.rhodesianus.v1.2008

(C) 2008 by Chelonian Research Foundation • Published 15 May 2008

\title{
Pelusios rhodesianus Hewitt 1927 - Variable Mud Turtle, Variable Hinged Terrapin
}

\author{
Donald G. Broadley ${ }^{1}$ and Richard C. BoycotT ${ }^{2}$ \\ ${ }^{1}$ Biodiversity Foundation for Africa, \\ P.O.Box FM 730, Famona, Bulawayo, Zimbabwe [broadley@gatorzw.co.uk]; \\ ${ }^{2}$ P.O. Box 5245, Mbabane, Swaziland [richjude@realnet.co.sz]
}

Summary. - The variable hinged terrapin, Pelusios rhodesianus (Family Pelomedusidae), is a moderate-sized species that inhabits weedy shallow dams and backwaters from Lake Victoria south to KwaZulu-Natal, South Africa. The populations in the main part of the species' range seem to be in good shape and the construction of storage dams provides additional suitable habitats for $P$. rhodesianus. However, some of the peripheral southern populations in South Africa (KwaZuluNatal) are threatened or extinct.

Distribution. - Angola; Botswana; Burundi; Congo (DRC); Congo (ROC); Mozambique; Namibia; Rwanda; South Africa; Tanzania; Uganda; Zambia; Zimbabwe. Central and Eastern Africa from Republic of Congo in the northwest to Lake Victoria region in the northeast, south to eastern South Africa.

Synonymy.-Pelusios nigricans rhodesianus Hewitt 1927; Pelusios subniger rhodesianus; Pelusios rhodesianus; Pelusios castaneus rhodesianus; Pelusios rhodesianus rhodesianus.

SuBSPECIES. - None recognized. Morphology suggests possible north-south geographic variation.

STATUS. - IUCN 2007 Red List: Least Concern (LR/lc) (assessed 1996, needs updating); CITES: Not Listed.

Taxonomy. - Pelusios nigricans rhodesianus was described by Hewitt (1927) on the basis of a series of shells from the Mpika District of Zambia.Loveridge (1941) placed this taxon in the synonymy of $P$. subniger and various other authors listed materials under $P$. castaneus. Laurent (1965) revived rhodesianus as a subspecies of $P$.castaneus, butRaw (1978), finding these two taxa to be sympatric in Natal, raised rhodesianus to specific rank, this status being subsequently confirmed by Broadley (1981) and Bour (1983).
Broadley (1981) suggested that this species might be divided into subspecies on the basis of the head coloration, those from north of the South Equatorial Divide usually having the head brown with yellow vermiculation, while those from the south usually have uniform brown heads.

Description. - Pelusios rhodesianus is a moderatesized terrapin (maximum carapace length $25.5 \mathrm{~cm}$ ) having an oval, moderately domed shell, with vertebral keels weak or absent; the posterior margin of the carapace is rounded.

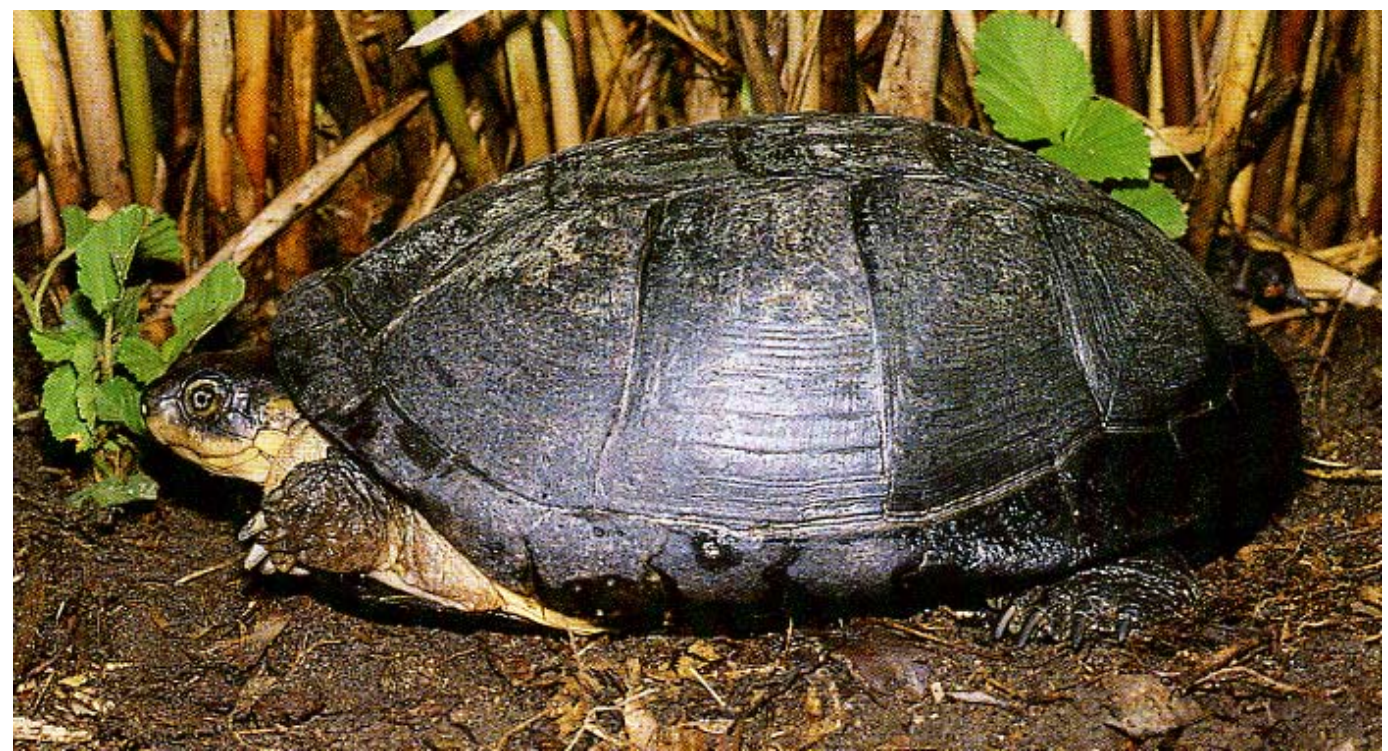

Figure 1. Pelusios rhodesianus: an adult from the Lake St. Lucia area, KwaZulu-Natal, South Africa. Photo by Richard C. Boycott. 


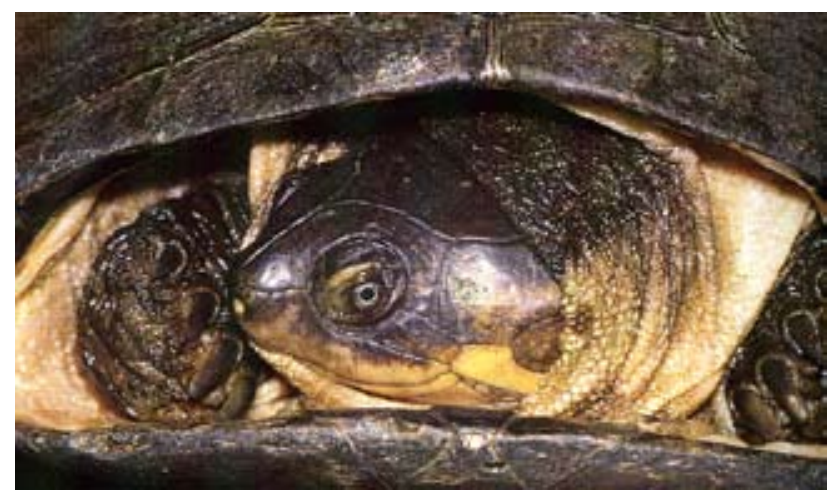

Figure 2. Pelusios rhodesianus: head of an adult from the Lake St. Lucia area, KwaZulu-Natal, South Africa. Photo by Richard C. Boycott.

Growth rings on the epidermal shields are usually well defined. The plastral hinge is well developed, with the anterior lobe less than twice the length of the abdominal sulcus. The head is moderately wide, less than half the width of the plastron at the abdomino-femoral sulcus; the beak is bicuspid, with two mental barbels. Falciform scales on the forelimbs are well developed.

There are eight neural bones, with N8 sometimes elongate and in contact with the suprapygal.

The carapace and bridge are black, the plastron may be black, with or without irregular yellow patches mesially, or uniform yellow. The head is brown above, with or without yellow vermiculation, the sides of the head and skin of the neck and limbs are yellowish, but gray-brown on outer faces of the limbs.

Distribution. - In Central and East Africa, it is widespread in Rwanda and Burundi, and found in lagoons and weedy estuaries bordering Lakes Victoria, Tanganyika, and Malawi, probably also in Lake Rukwa (Spawls et al. 2000). It extends south from the Democratic Republic of Congo and Zambia to Angola, northern Botswana, and Zimbabwe, with apparently relict populations in eastern South Africa (KwaZulu-Natal). The South African populations are apparently disjunct, with no known localities for $P$. rhodesianus in the Limpopo River basin of southern Mozambique, where $P$. sinuatus and $P$. subniger occur, or the eastern coastal areas, where $P$. castanoides and $P$. subniger occur.

Habitat and Ecology. - This species occurs in a variety of habitats, including temporary pans, extensive swamp areas like those surrounding Lake Bangweulu in Zambia (from where the type series probably originated) and larger water bodies, including Lake Victoria and many man-made dams, where the species favors quiet weedy backwaters (pers. obs.). This terrapin was found to be inhabiting the dense mat of water hyacinth (Eichhornia crassipes) when this noxious weed was being removed from Lake Chivero near Harare in Zimbabwe (pers.obs.). Specimens from the swamp areas of Zambia

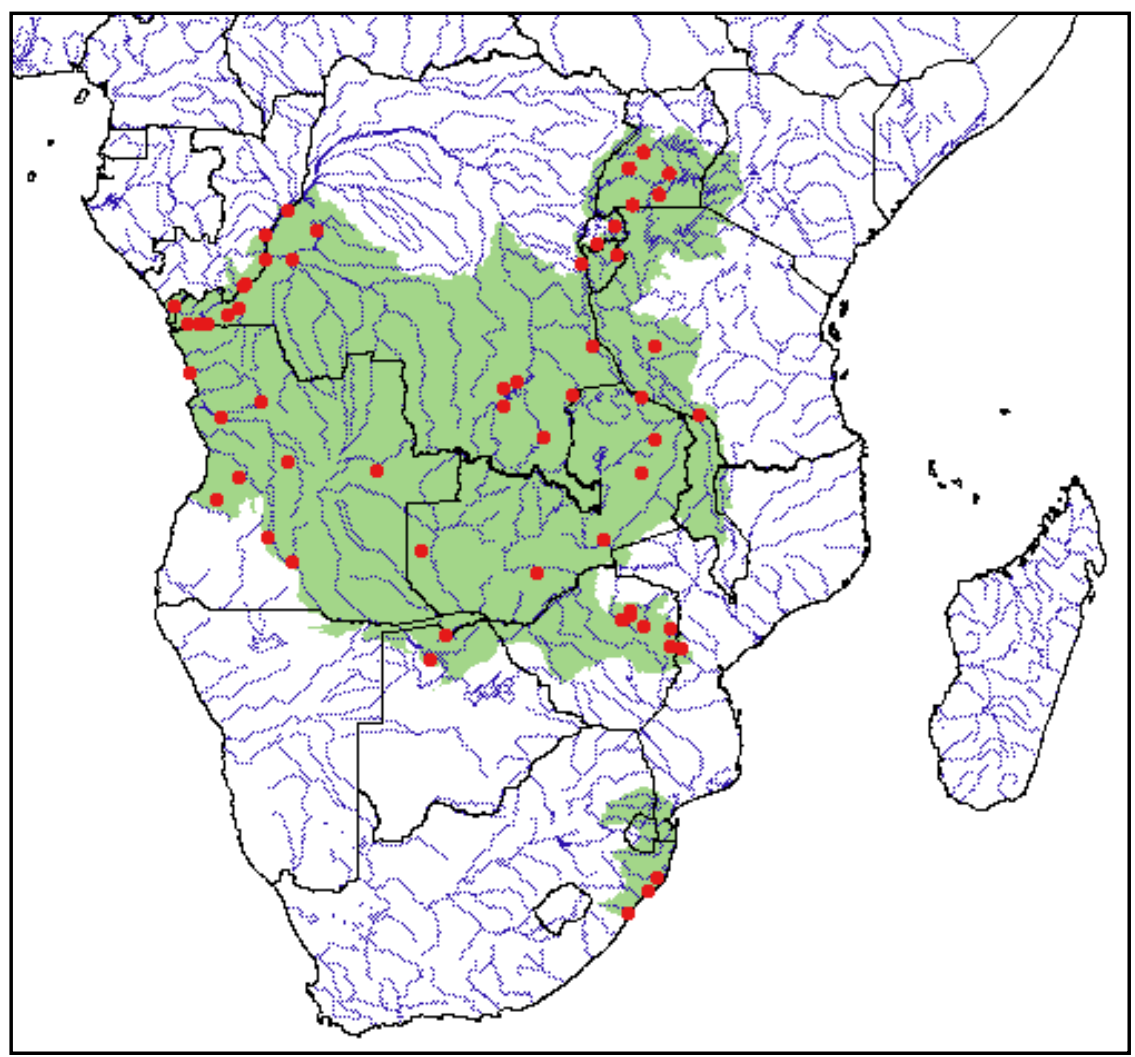

Figure 4. Distribution of Pelusios rhodesianus in Africa. Red points = museum and literature occurrence records based on Iverson (1992) plus more recent and authors' data; green shading = projected distribution based on GIS-defined hydrologic unit compartments (HUCs) constructed around verified localities and then adding HUCs that connect known point localities in the same watershed or physiographic region, and similar habitats and elevations as verified HUCs (Buhlmann et al., unpubl. data), and adjusted based on authors' data. 
often show fire damage to the carapace, caused when bush fires rage through the dry reed beds during the dry season, when the terrapins are aestivating in the mud.

The diet of this species probably consists largely of mollusks and aquatic insects, but they also feed on the stems, leaves, and flowers of aquatic plants. In captivity they play havoc with water lilies by biting through the stems of the flower bulbs and leaves (pers. obs.).

Reproductive data on the species are few; on 13 September 1958, B.L. Mitchell (pers. comm.) examined 31 female $P$. rhodesianus walking about in seasonally inundated grasslands on the Kafue Flats in Zambia, apparently in search of suitable sites for oviposition, one 199 mm CL female contained 18 eggs measuring 33 to 37 x 22 to $23 \mathrm{~mm}$. A $170 \mathrm{~mm} \mathrm{CL}$ female from the Mpudzi River, Zimbabwe, contained 13 eggs measuring 33 x $20 \mathrm{~mm}$ in November, and a $139 \mathrm{~mm}$ CL female from Norton laid 11 eggs of similar size in captivity during April/May.

Population Status. - The populations in the main part of the species' range seem to be in good shape and the construction of storage dams provides additional suitable habitats for P.rhodesianus. However, some of the peripheral southern populations in South Africa (KwaZulu-Natal) are threatened or extinct.

Threats to Survival. - In KwaZulu-Natal, this species may suffer from loss of habitat as a result of the filling-in or drainage of swamps, marshes, pans, and vleis. At some localities pollution of the habitat undoubtedly affects terrapins. The long-term effects of insecticide spraying for the control of mosquitoes is unknown and doubtless poses an additional threat to their survival. Veldt fires in the dry seasons could affect hibernating terrapins since they are only shallowly buried (Boycott 1988).

Conservation Measures Taken. - This species is listed as "Peripheral" in the South African Red Data Book - Reptiles and Amphibians (1988). It occurs in Provincial nature reserves at Kosi Bay and Lake St. Lucia, but the southernmost population at Durban Bluff is now believed to be extinct according to a survey by Bourquin (2004). The nearest surviving populations are in an unprotected area just south of Umlalazi Nature Reserve (Mtunzini), in pans behind the coastal dunes, but there is evidence that these terrapins are being wantonly killed by local people.

Conservation Measures Proposed. - In South Africa the species should be afforded general protected status under the KwaZulu-Natal Provincial Nature Conservation
Ordinance and additional reserves should be proclaimed throughout its range (Boycott 1988).

Captive Husbandry. - No information.

Current Research. - None known.

Acknowledgments. - We are grateful to David Blake for providing specimens for photography at the St. Lucia Crocodile Centre.

\section{LITERATURE CITED}

Bour, R. 1983. Trois populations endémiques du genre Pelusios (Reptilia, Chelonii, Pelomedusidae) aux îles Seychelles; relations avec les espèces africains et malagaches. Bull. Mus. natn. Hist. nat., Paris, (4)2, Sec. A 1:343-381.

Bourquin,O. 2004.Reptiles (Reptilia) in KwaZulu-Natal: 1 - diversity and distribution. Durban Museum Novitates 29:57-103.

Bоусотт, R.C. 1988. Species account for Pelusios rhodesianus. In: Branch, W.R. (Ed.). South African Red Data Book - Reptiles and Amphibians. South African National Scientific Programmes, Report No. 151, pp. 173-174.

BoYCOTT,R.C. AND BOURQUIN, O. 2000. The southern African tortoise book: a guide to southern African tortoises, terrapins and turtles. O. Bourquin, Hilton, KwaZulu-Natal, South Africa, 228 pp.

Broadley, D.G. 1981. A review of the genus Pelusios Wagler in southernAfrica (Pleurodira: Pelomedusidae).Occ.Pap.Nat. Mus. Mon. Rhod. Ser. B, Nat. Sci. 6(9):633-686.

HewitT, J. 1927. Further descriptions of reptiles and batrachians from South Africa. Rec. Albany Mus. 3:371-415.

IVERSON,J.B.1992.ARevisedChecklist withDistribution Maps of the Turtles of the World. Richmond, IN: Privately Printed, 363 pp.

LAURENT, R.F. 1965. A contribution to the knowledge of the genus Pelusios (Wagler). Annls. Mus. R. Afr. Cent., Sér. 8, 135:1-33.

Loveridge, A. 1941. Revision of the African terrapin of the family Pelomedusidae. Bull. Mus. Comp. Zool. 88:465-524.

Raw, L.R.G. 1978. Taxonomic notes on the hinged terrapins, genus Pelusios, of Natal. Durban Mus. Novit. 11:287-294.

Spawls, S., Howell, K., Drewes, R., And Ashe, J. 2002. A field guide to the reptiles of East Africa (Kenya, Tanzania, Uganda, Rwanda and Burundi). Academic Press, San Diego, 543 pp.

\section{Citation Format for this Account:}

Broadley, D.G. And Boycott, R.C. 2008. Pelusios rhodesianus Hewitt 1927 - variable mud turtle, variable hinged terrapin. In: Rhodin, A.G.J., Pritchard, P.C.H., van Dijk, P.P., Saumure, R.A., Buhlmann, K.A., and Iverson, J.B. (Eds.). Conservation Biology of Freshwater Turtles and Tortoises: A Compilation Project of the IUCN/SSC Tortoise and Freshwater Turtle Specialist Group. Chelonian Research Monographs No. 5, pp. 004.1-004.3, doi:10.3854/crm.5.004 .rhodesianus.v1.2008, http://www.iucntftsg.org/cbftt. 